FAMILY IV.*-CAPRIMULGIN Æ. GOAT-SUCKERS.

Genus I.†-CAPRIMUlgus, Linn. GOAT-SUCKER.

N U T T A L L'S WHIP-P O O R-W I L L.

Caprimulgus Nuttallit, Aud.

\title{
PLATE CCCCLXLV.-MALE.
}

How little did I think whilst at Edinburgh, in the year 1839, that I would have found and procured Nuttall's Whip-poor-will, in the course of my rambles on the Upper Missouri, in the year 1843. At the former date I gave an intimation of the existence of such a bird in my fifth volume of Ornithological Biographies, at page 335, to which you, reader, may refer if you please.

On Thursday the 7th of September, 1843, we were forced to land our boat on the eastern side of the Missouri river, on account of the wind, which at that time blew too high for us to proceed; for, reader, whenever the wind is strong, the waters of the Missouri become at once ruffed, and the navigation by no means secure. We halted at a place where we thought we could spend the time in hunting, with some advantage, and the moment our Mackinaw boat was tied to the trees on the shore, each man, bearing a gun, sallied forth in search of such game as I was anxious to procure. Elks were abundant, and we saw a great number of them, some were snapped at within a few paces, others were shot at at considerable distances; but Mr. CuLBERTSON, (the superintendent of Fort Union, who accompanied us as far as Fort Pierre, and his Indian wife and young son who were of the party,) had the good fortune to shoot and kill a fine young male, of which I will speak elsewhere. The woods were thickly matted and difficult of ingress; some went up the river, whilst others followed a contrary course; some Sharptailed Grouse were started, shot at, and brought to our camp. In the course of the night the wind blew so violently, that all on board resorted to the shore, Mrs. Culbertson leaping first on shore with her babe in her arms, 

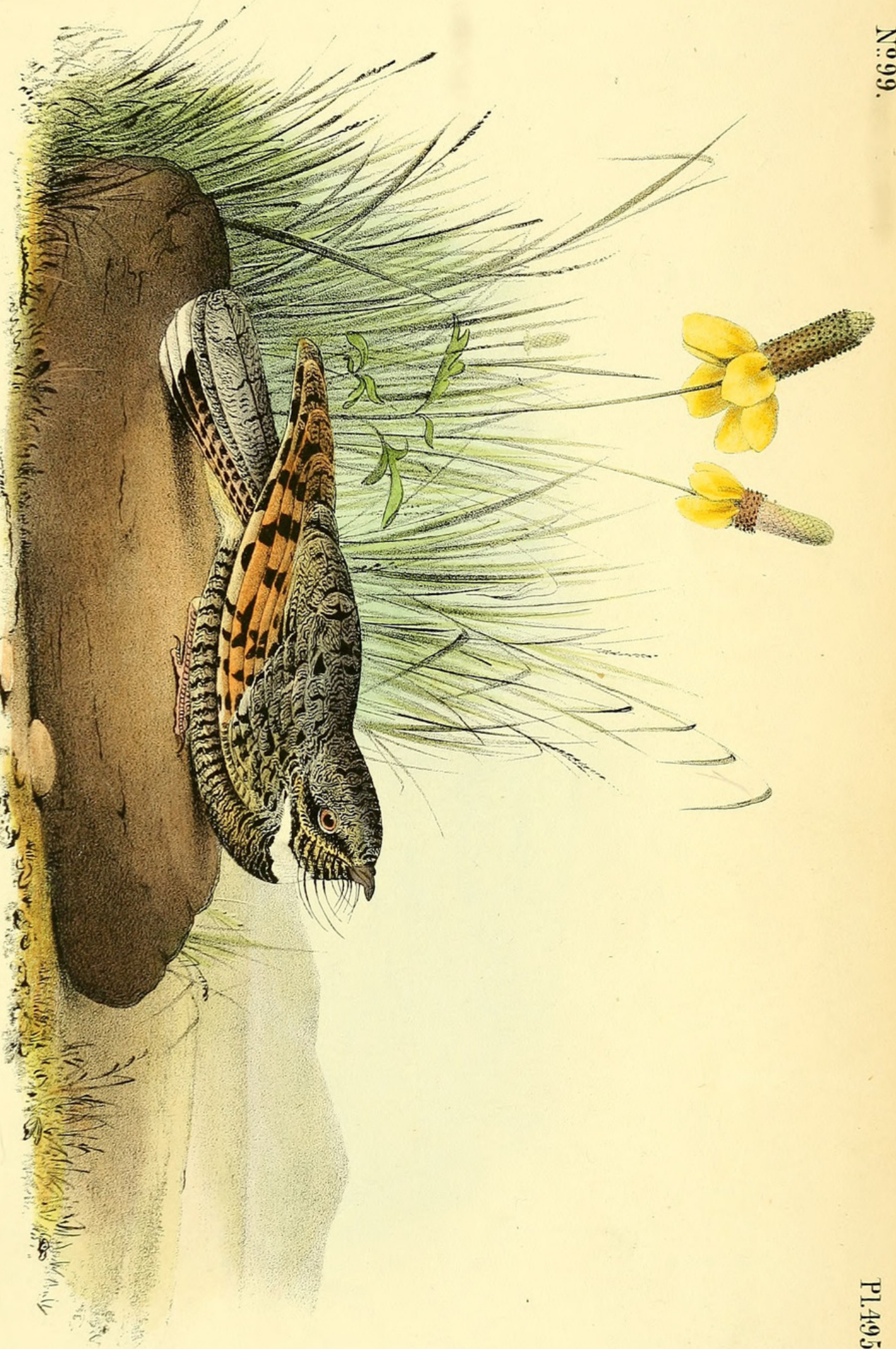

when she in a few moments found a shelter of willow branches, \&c., under which both remained until the storm had subsided.

The next morning the wind was still blowing too hard for us to proceed, and as on the former day, the hunters went off in many directions. Mr. J. G. BELL, on his return from a walk up the river shore, where he had shot some Wild Pigeons, started the individual now before you from the ground. It flew a few yards, and my young companion took it for our common Whip-poor-will; but on its second rising and flying again before him, he saw that it was a much smaller bird, fired at it, and fortunately brought it to me, fresh and beautiful though dead.

On the evening of the next day, about ten o'clock, my friend Harris called me to hear the notes of this bird. We had removed to an island a mile or so below where the Whip-poor-will had been procured; and on ascending the bank and entering the dried, rank grass of the prairie, the notes of the birds came at once on our ears, for there were two of them, both anxiously desirous, one might have thought, to convey to us all that they could perform in lieu of a song. The sounds we heard, were indeed those of a Whip-poor-will, cut short of much of their compounds, for it was reduced to the syllables Oh-will, Oh-will, Oh-will, repeated often and as quickly as is the fashion of our own common species.

Those birds were then on their passage southward, and I regret to say that nothing can now be added to their habits. I am also sorry that no specimens of the female were seen or procured.

This pretty species I have, as you perceive, named after my friend Thomas Nuttald, whose worth as a man and a scientific naturalist, are both so well known.

Nuttall's Whip-poor-will, Caprimulgus Nuttallii, Aud.

$7 \frac{1}{4}$.

Prairies of Western Missouri, and the Northern Territories.

Adult Male.

Bill black, iris dark hazel. Feet reddish-purple, the scales and claws darker. The general colour of the upper parts is dark brownish-grey, lighter on the head and medial tail feathers, which extend beyond the others half an inch, and all of which are streaked and minutely sprinkled with brownishblack and ash-grey. The quills and coverts are dull cinnamon colour, spotted in bars with brownish-black; the tips of the former mottled with light and dark brown. Three lateral tail feathers barred with dark brown and cinnamon, and tipped with white. Throat brown, annulated with black, a band of white across the fore neck; beneath the latter black mixed 
with bars of light yellowish-grey and black lines; under tail coverts dull yellow.

Total length $7 \frac{1}{4}$ inches; bill along the edge $\frac{7 \frac{1}{8}}{8}$; wing from flexure $5 \frac{3}{4}$. Second quill longest, third almost equal. Tail to the end of the upper feathers $3 \frac{1}{2}$; tarsus $\frac{5}{8}$; middle toe $\frac{5}{8}$, its claw $\frac{1}{4}$. Strongly pectinated.

\section{FAMILY XXIX.*-COLUMBINÆE. PIGEONS.}

Genus I.†-COLUMBA, Linn. DOVE.

\section{TEX A N T U R T L E-D O V E.}

Columba Trudeauit, Aud.

\section{PLATE CCCCLXLVI.-MALE.}

I am indebted for this new species to my companion Mr. J. G. BELL, who received it from Texas; but, unfortunately, no notes connected with the habits of this handsome Dove were forwarded by the person who procured it.

In naming it after my excellent friend Doctor TrudeaU, of New York, I only pay another very slight tribute to his great attainments as an accomplished ornithologist and student of nature.

\section{Texan Turtue-Dove, Columba Trudeauii, Aud.}

$10 \frac{1}{2}$.

One specimen, procured in Texas.

Male.

Upper part of the head and neck purplish, with rich reflections of goldengreen on the hind parts; a black spot on the sides of the throat, and bill black; throat and neck purplish-buff; sides and under wing coverts ash-grey, as well as the lower tail coverts; vent white; shoulders, back and two middle tail feathers, brownish-olive; a large patch of white formed by the first row 

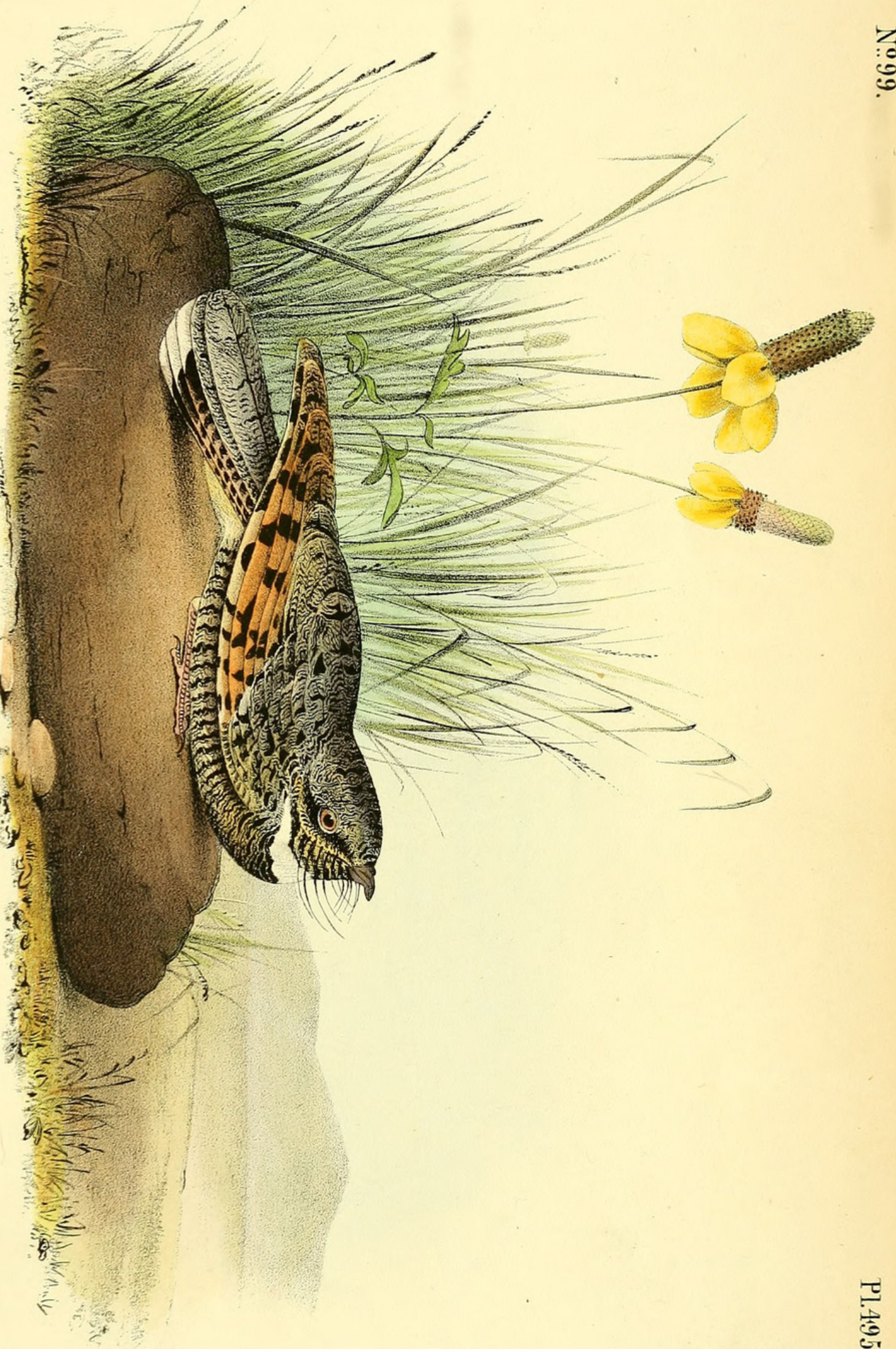


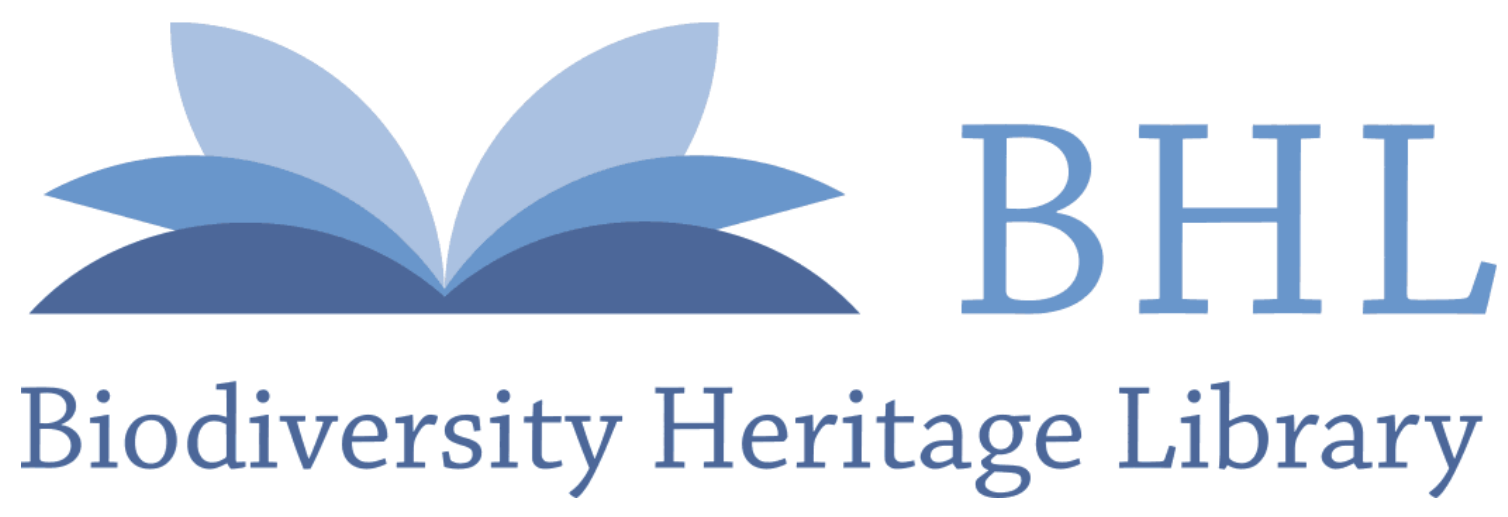

Audubon, John James. 1844. "Nuttall's Whip-Poor-Will, Caprimulgus nuttallii, Aud. [PI. 495]." The birds of America: from drawings made in the United States and their territories 7, 350-352. https://doi.org/10.5962/p.319612.

View This Item Online: https://www.biodiversitylibrary.org/item/124981

DOI: https://doi.org/10.5962/p.319612

Permalink: https://www.biodiversitylibrary.org/partpdf/319612

\section{Holding Institution}

Smithsonian Libraries

\section{Sponsored by}

Biodiversity Heritage Library

\section{Copyright \& Reuse}

Copyright Status: NOT_IN_COPYRIGHT

This document was created from content at the Biodiversity Heritage Library, the world's largest open access digital library for biodiversity literature and archives. Visit BHL at https://www.biodiversitylibrary.org. 